\title{
健診センター受診者における $\mathrm{HCV}$ 抗体陽性者の検討
}

村山 優子 小田 福美 新谷 和夫

\section{目 的}

当施設では，1994 年 5 月の開設当初より，C 型肝炎 のスクリーニングとして第二世代 HCV 抗体検査を実 施してきた。実施後, 約一年が経過し, 当施設におけ る陽性率および肝機能検査との関連, また, 再受診陽 性者の経過を追跡し若干の知見を得たので報告する。

\section{対象および方法}

1994 年 5 月から 1995 年 8 月までの当施設を受診し た男性 4,573 名, 女性 4,079 名の合計 8,652 名を対象 に, 第二世代 $\mathrm{HCV}$ 抗体検査 (イムチェック $\mathrm{F}-\mathrm{HCV}-$ $\mathrm{Ab}$ ：国際試薬）を行ない, Cut-Off-Index（以下 C. O. I） 1.0 以上の抗体陽性者 243 名について, 肝機能検査 との関連を調べた。また, 243 名のうち同期間内に再受 診した 42 名の抗体価および肝機能検查の変動を追跡 した。

\section{成績と考察}

当施設での陽性率は, $2.8 \%(243 / 8,652)$, 男女別で は, 男性 2.6\% $(123 / 4,573)$, 女性 3.0\% $(123 / 4,079)$ であった。陽性者の平均年齢は, $56.2 \pm 10.6$ 歳であり, 年齢階級別に陽性率をみると，男女とも高齢になるに 従い高くなっていた。特に, 10 代から 40 代までの陽性 率が，1.4\%に対し，50 代以上では，4.1\%で急激に高 くなっている。

次に，抗体陽性者を， C. O. I.50 以上の高抗体価， C. O. I.50 以下の低抗体価別, さらにそれらを, ALT 36 $\mathrm{IU} / \mathrm{L}$ 以上の肝機能異常のもの, ALT $36 \mathrm{IU} / \mathrm{L}$ 以下の

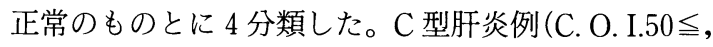

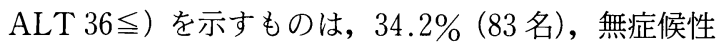

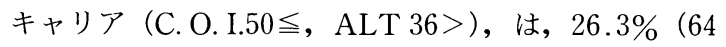

名), 過去の一過性感染例 (C. O. I.50>, ALT 36>) は，35.0\% (85 名), その他 4.5\%（11名）は, 低抗体 価にもかかわらず肝機能異常を示し，その原因として アルコール性肝障害, $\mathrm{HBs}^{-} \mathrm{Ag}$ 陽性の重複感染例が ALT の異常值になる要因ではないかと考えられた。 次に, 再受診者のうち, HCV 抗体陽性者 42 名につ いて, 初診時と再受診後における抗体価, および ALT 価の変動を調べた。抗体価については, 低抗体価群, 高抗体価群ともに, C. O. I. 值に変動はみられなかっ た。ALT 值については, 初診時に低抗体価で, ALT 36 以下のものは, 再受診時においても変動はみられず, ALT 36 以上であった例については, $\gamma-\mathrm{GTP}$ の改善と ともに, ALT 值の改善がみられた。一方, 高抗体価例 における ALT 值の変動は，初診時に ALT が 25 であ ったものが, 125,44 のものが 271 というような明らか な上昇を示す例や，デー夕的には，初診時には，無症 候性キャリアと思われた例が, 再受診後には, C 型肝炎 へと悪化した例が，12 名中 4 名にみられた。

さらに, ALT 值の差 (初診時 ALT 值一再診時 ALT 値）を低抗体価, 高抗体価（無症候性キャリア）別に みると，高抗体価を示した受診者は，低抗体価の受診 者に比べ, ALT 值は, 有意に $(p<0.05)$ 上昇してい る。

\section{まとめ}

抗体陽性者の 6 割が肝機能異常を示さず，この検査 の有用性が示唆された。さらに, HCV 抗体の陽性者の 状態をみるうえで，C. O. I. 值および ALT 值の参考に することは重要であり, 再受診者の場合, ALT 值の変 動にも注意していく必要があると思われた。

\section{Evaluation of Patients with Hepatitis C Virus (HCV) Antibody in AMHTS}

東京簡易保険総合健診センター 